\title{
Akumulasi Kapital, Penghancuran Gerakan Kiri, dan Kemiskinan di Nusa Tenggara Timur
}

Oleh:

\author{
Didimus Dedi Dhosa ${ }^{1}$
}

\begin{abstract}
Abstraksi
Kemiskinan di Nusa Tenggara Timur dalam anggapan banyak pihak disebabkan oleh faktor seperti alam yang tandus, infrastruktur yang kurang memadai, sumber daya manusia yang minim, perilaku korup para pejabat publik, serta minimnya penerapan prinsip-prinsip good governance dalam tata kelola pemerintahan. Berbeda dengan pandangan di atas, tulisan ini melalui pendekatan ekonomi politik yang berusaha menelusuri jejak sejarah hingga era kolonial, berargumen bahwa kemiskinan di Timor disebabkan oleh akumulasi kapital dan penghancuran gerakan sosial kiri sampai ke akar-akarnya. Akumulasi kapital berlangsung bukan saja pada cara primitif melainkan juga dengan cara penjarahan yang meliputi sejarah panjang kolonialisme, privatisasi dan komodifikasi. Melalui akumulasi kapital Timor yang dahulu kala dikenal sebagai lumbung cendana dirampok hingga punah demi pembangunan negeri-negeri kolonial, bahkan pengelolaannya didominasi oleh negara pascakolonial. Selain itu, penguasaan agraria dan peternakan di Timor didominasi oleh segelintir elit tradisional yang terus mengalami metamorfosis kepemilikan pada kaum elit kontemporer. Kenyataan semacam itu diperburuk oleh adanya penghancuran gerakan sosial kiri pada tahun 1965 yang sebelumnya mendorong perjuangan keadilan distributif agraria dan kepemilikan ternak secara lebih merata di Timor.
\end{abstract}

Kata kunci : kemiskinan di Nusa Tenggara Timur, akumulasi kapital, gerakan kiri.

\begin{abstract}
Some parties considered that the poverty in East Nusa Tenggara caused by several factors, for instance; the condition of its barren nature, inadequate infrastructure, minimal human resources, corrupt behaviors among public officials, and lacking good governance. In contrast to such view, this article attempts to trace a historical root of the poverty in Timor since the colonial era until nowadays, through a political economy approach. It argues that poverty in Timor is mainly caused by the accumulation of capital and the destruction of the leftist movement (left wing politics). The accumulation of capital takes place not only in primitive procedures, indeed it includes deprivation of the society due to privatization and commodification. Timor was once famous for its sandalwood comodity, but under colonialism such local commodity experienced extinction for the expense of the development in the colonial country. In postcolonial era, it is worsen due to mismanagement as the comodity is no longer favorable and the development process prioritizes other agrarian commodities. Moreover, the agrarian and stockbreeding development in Timor is dominated by a handful of traditional elites who continue to extend the metamorphosis of ownership in contemporary elites. The reality is aggravated by the destruction of the leftist movement in 1965 which previously stimulated mass action in Timor for fighting agrarian distributive justice and evenly livestock ownership.
\end{abstract}

Keywords: poverty in East Nusa Tenggara, accumulation of capital, leftist movement

\footnotetext{
1 Didimus Dedi Dhosa adalah staf pengajar di FISIP Unika Widya Mandira, Kupang-NTT. Penulis menyelesaikan studi S2 Sosiologi pada program Pascasarjana Sosiologi UGM tahun 2012.
} 


\section{A. Pendahuluan}

Trend pertumbuhan ekonomi dan pendapatan perkapita Propinsi Nusa Tenggara Timur (NTT) terus merangkak naik saban tahun, acapkali membuat pemerintah daerah merasa berbangga. ${ }^{2}$ Trend pertumbuhan ekonomi itu, seperti didaku mazhab neoliberal (Heertz 2004:24), bakal menghadirkan trickle down effect untuk membuka pasar kerja baru, menyerap tenaga kerja, dan mencegah derasnya aliran buruh migran dari NTT.

Tapi, melihat profil orang miskin dan tenaga kerja ilegal dikirim ke luar negeri dua tahun terakhir (2016-2017) membuat indeks pertumbuhan ekonomi, pendapatan perkapita, serta tricke down effect tampak tidak bermakna sama sekali. Pada tahun 2016 penduduk miskin NTT mencapai 1 juta lebih orang atau 22,01 persen. Persentase kemiskinan di pedesaan relatif menurun apabila disandingkan dengan periode sebelumnya, sementara itu persentase kemiskinan semakin terkonsentrasi di perkotaan (BPS Propinsi NTT 2016). Semenjak tiga semester pertama, terhitung Januari-Maret 2017, jumlah tenaga kerja Indonesia (TKI) ilegal asal NTT dikirim ke luar negeri sudah mencapai 4.796. Sejak Januari hingga Maret 2017, terdapat 26 TKI NTT meninggal dunia, dengan rincian 25 TKI ilegal, 1 TKI legal (Pos Kupang, 6 April 2017, hlm. 13). Menurut Kepala Balai Pelayanan Penempatan dan Perlindungan Tenaga Kerja Indonesia (BP3TKI) Kupang, Tato Tirang, wilayah penyumbang TKI terbesar berasal dari 5 daerah yakni Kabupaten Kupang, Timor Tengah Selatan, Timor Tengah Utara, Belu, dan Kota Kupang (Victory News, 29 Maret 2017). Kelima wilayah itu terdapat di pulau Timor yang menjadi locus studi ini.

Kemiskinan di NTT, menurut penelitian pengembangan wilayah dari perspektif sosial, oleh Lembaga Ilmu Pengetahuan Indonesia (LIPI) disebabkan antara lain wilayahnya yang sebagian besar kering dan tandus, buruknya kondisi jalan raya, transportasi dan jaringan komunikasi, rendahnya kualitas sumber daya manusia (SDM), penegakan hukum dan kualitas layanan publik, penyelewengan terhadap dana bantuan penanggulangan kemiskinan dan peningkatan kesehatan masyarakat, serta rendahnya kapasitas pemerintah lokal untuk meningkatkan pendapatan asli daerah (Wuryandari 2014:4-7). Untuk mengatasi kemiskinan, peneliti LIPI merekomendasikan pengembangan otonomi daerah berbasis prinsip-prinsip good governance serta pengembangan kapasitas (capacity building) (Wuryandari 2014:139-166). Para peneliti LIPI tampak percaya bahwa negara sangat netral dalam proses pembangunan dan yakin bahwa perbaikanperbaikan teknis melalui pengembangan kapasitas dapat mengeluarkan NTT dari kemiskinan (Li 2012:225; Tolo 2016:174-175).

Studi tentang kemiskinan di NTT oleh tim LIPI tersebut dinilai cukup problematis, tidak mendasar, dan karena itu tidak bisa diterima sepenuhnya secara rasional. Argumentasi dan rekomendasi para

\footnotetext{
${ }^{2}$ Indeks pertumbuhan ekonomi NTT 5,63\% (2010-2012), 6,0\% (2013), 6,25\% (2014). Meski tampak menurun pada tahun 2016 sebesar 5,18\% tapi pertumbuhan itu masih di atas rata-rata pertumbuhan ekonomi nasional. Sedangkan pendapatan per kapita terus meningkat yakni 4,5 juta rupiah (2008), 5,7 juta rupiah (2010), 6,1 juta rupiah (2011), dan 7,8 juta rupiah (2014).
} 
Jurnal Pemikiran Sosiologi Volume 4 No. 2, 2017

Akumulasi Kapital, Penghancuran Gerakan Kiri, dan Kemiskinan di Timor

Didimus Dedi Dhosa

peneliti LIPI mirip pandangan kaum modernis dengan pendukung utamanya adalah Rostow (1960), Hoselitz (1960), Pye (1962), Parsons (1964), dan McCelland (1967). Di Indonesia, teori modernisasi dalam pembangunan mulai berkembang pesat pada tahun 1950 -an, persis pada saat kajian Indologi Hinda-Belanda melempem bersamaan dengan kekalahan politik Belanda, dan masa depan ilmu-ilmu sosial kemudian berkiblat pada sosiologi Parsonian Amerika Serikat (Samuel 2010:76). Teori modernisasi klasik melihat "negara sebagai agen pembangunan" (Hadiz 2005:173), yang menjelma kembali dalam wujud neoinstitusionalisme dan teori pilihan rasional (rational choice theory). Kelemahan mendasar teori modernisasi adalah mengabaikan aspek ekonomipolitik yang penuh dengan benturan kepentingan (Hadiz 2005:174), sulit menjelaskan ketimpangan pertumbuhan antara negara-negara di dunia pertama dan dunia ketiga, serta tidak mampu menguraikan terjadinya pemiskinan sistemik negara-negara di penjuru dunia (Frank 1966:2).

Berbeda dengan pendekatan teknis-modernisasi a la LIPI, tulisan ini menggunakan pendekatan ekonomi politik. Pendekatan ekonomi politik melihat "persoalan menyangkut penguasaan alat-alat produksi, serta struktur hukum dan kekuasaan yang menopang berlangsungnya ketimpangan sistemik" (Li 2012:21). Melalui pendekatan ekonomi-politik, tulisan ini berargumen bahwa kemiskinan di Timor disebabkan oleh akumulasi kapital dan penghancuran gerakan kiri. Akumulasi kapital bukan hanya melalui cara-cara primitif (primitive accumulation) sebagaimana dikemukakan Karl Marx, melainkan juga dengan cara penjarahan (accumulation by dispossession) seperti ditegaskan
David Harvey (2003) yang meliputi sejarah panjang kolonialisme, serta privatisasi dan komodifikasi. Akumulasi kapital yang berlebihan (over accumulation) telah menyebabkan konsentrasi kepemilikan modal pada segelintir elit di satu sisi, dan serentak mengekslusi massa rakyat dari sumber sosial-ekonomi di sisi yang lain.

\section{B. Metode dan Kerangka Analisis: Kemiskinan dan Akumulasi Kapital}

Artikel ini ditulis dengan menggunakan pendekatan kualitatif melalui pendekatan studi historis kritis. Sumber bacaan dan data yang digunakan untuk menulis artikel ini berasal dari sejumlah literatur seperti buku, disertasi, jurnal dan media massa cetak yang sesuai dengan tema penelitian.

Melihat kelemahan teori modernisasi dalam pembangunan, maka penulis kemudian memakai pendekatan ekonomi politik sebagai kerangka analisa untuk menjelaskan proses akumulasi kapital dan penghancuran gerakan kiri yang berdampak pada upaya sistematis mengekslusi massa rakyat dari sumber sosial ekonomi. Ekonomi politik adalah sebuah pendekatan yang melihat proses penguasaan terhadap alat-alat produksi, serta struktur hukum dan kekuasaan yang menopang ketimpangan sistemik dalam masyarakat. Tulisan ini pun menggunakan pendekatan historis kritis untuk melihat sebab musabab kemiskinan di Timor.

Kerangka teoritik yang digunakan sebagai alat analisis dalam pembahasan mengenai kemiskinan di Timor menggunakan konsep mengenai akumulasi kapital. Akumulasi kapital dapat dibedakan (meski tidak terdapat batasan tegas, lebih tepat 
Jurnal Pemikiran Sosiologi Volume 4 No. 2, 2017

Akumulasi Kapital, Penghancuran Gerakan Kiri, dan Kemiskinan di Timor

Didimus Dedi Dhosa

dikembangkan lebih lanjut) ke dalam dua hal berikut ini: 'akumulasi primitif' (primitive accumulation) diperkenalkan oleh Karl Marx (2004), dan 'akumulasi melalui penjarahan' (accumulation by dispossession) yang dikembangkan David Harvey (2003).

Konsep Marx tentang akumulasi primitif lahir sebagai kritik terhadap pandangan Adam Smith tentang akumulasi kapital yang Marx nilai a-historis. Smith mendaku bahwa pasar kapitalis digerakan oleh invisible hand yang adil, dan karena itu ia akan menciptakan kesejahteraan bagi semua peserta yang terlibat di dalam pasar. Tapi bagi Marx, pasar kapitalis tidak pernah bersifat adil dan netral, sebab pasar kapitalis berlangsung dalam kondisi penuh pemaksaan, penindasan dan eksploitasi akut (Mulyanto 2012:41-45). Relasi sosial di bawah sistem kapitalisme bagi Marx dicirikan oleh terlepasnya massa rakyat dari sarana produksi, dan dalam kondisi demikian, akumulasi primitif dapat berlangsung dengan baik (McNaughton 2015:293).

Marx menyatakan bahwa akumulasi primitif merupakan "proses historikal penceraian produsen dari alat-alat produksi". Dikatakan primitif, lanjut Marx karena akumulasi itu merupakan "pra-sejarah kapital, dan dari cara produksi yang bersesuaian dengan kapital" (Marx 2004:798). Di dalam gerak historis tersebut para produsen diubah menjadi pekerja upahan sesudah basis produksinya dirampok.

Ajegnya akumulasi kapital disebabkan oleh nilai lebih. Nilai lebih ini, demikian Marx, mengandaikan produksi kapitalis. Dan, produksi kapitalis pun bisa berlangsung apabila tersedia masa kapital yang didukung oleh ketersediaan tenaga kerja yang sudah terlepas dari basis produksi (Marx 2004:796). Cikal bakal nilai lebih berawal dari uang, kemudian menjadi kapital, dari kapital menjadi nilai lebih, dan dari nilai lebih dipakai untuk menambah akumulasi kapital dalam jumlah yang lebih besar lagi. Perampasan terhadap tanah-tanah milik petani, pengusiran dan penyerobotan atas tanah-tanah umum menjadi tanah milik pribadi menjadi prasyarat penting untuk mengeluarkan massa rakyat dari basis produksi, yang memungkinkan mereka menjadi tenaga kerja merdeka dalam produksi kapitalis. Hal ini didukung oleh pembuatan undang-undang sebagai alat perampokan tanah rakyat (Marx 2004: 809,821). Dalam konteks tertentu, peristiwa genosidal di Indonesia tahun 1965, oleh beberapa ilmuwan sosial dilihat sebagai bentuk dan prakondisi akumulasi primitif (McNaughton, 2015; Hadiz, 2015).

Harvey (2003:137-182) menyebut frase accumulation by dispossession sebagai perluasan praktek primitive accumulation sebagaimana disebutkan Marx, yang meliputi praktek penjarahan secara kolonial, privatisasi dan komodifikasi atas tanah. Akumulasi kapital merupakan salah satu tahap fundamental bagi ekspansinya kapitalisme. Awal mula, tanah diambil alih entah melalui perampasan, pengusiran para petani, pemindahan suku-suku dari tanah ulayat, maupun melalui otoritas negara yang merancang regulasi untuk mengeluarkan massa rakyat dari lahan produktif. Sesudah proses pengalihan itu berakhir, terciptalah paling tidak dua kelompok besar yang saling beroposisi: kaum feodal dan tuan tanah di satu sisi, dan kaum tanpa tanah, atau memiliki tanah namun tampak kecil ukurannya di sisi lain. Kaum yang tereksklusi dari basis produksi tersebut ditarik 
Jurnal Pemikiran Sosiologi Volume 4 No. 2, 2017

Akumulasi Kapital, Penghancuran Gerakan Kiri, dan Kemiskinan di Timor

Didimus Dedi Dhosa

masuk ke dalam sistem ekonomi kapitalistik (Mulyanto 2012:xiii, 45).

Pada akhir abad ke-16, di Inggris terjadi pengkaplingan "the commons" oleh para tuan tanah, yang dinamai "enclosure". Peralihan ini difasilitasi oleh negara melalui regulasi-regulasi (Mulyanto 2012:22-28). Sedangkan, di Indonesia enclosure dan proletarianisasi terjadi pada era Tanam Paksa (1830-1870) yang mulai berkembang pesat persis pada saat kaum borjuasi liberal Belanda menguasai Parlemen pada tahun 1870. Parlemen itu menerbitkan undang-undang pertanahan yang berlaku bagi koloni-koloni, termasuk Hindia Belanda. Melalui undang-undang itu, pemerintah kolonial menerbitkan sertifikat hak milik bagi lahanlahan garapan penduduk. Tanah yang tidak digarap, termasuk tanah ulayat, akan segera menjadi milik negara. Tanah milik warga bisa disewa tiap tahun, sedangkan tanah milik negara dapat disewa (Hak Guna Usaha) selama 75 tahun. Ini semua pada akhirnya mempercepat proses enclosure dan serentak membatasi akses masyarakat atas tanah (Mulyanto 2012:31-32).

Harvey menjelaskan bahwa pada tahun 1917, Negara Mexico memproteksi hak-hak masyarakat pribumi untuk memiliki tanah dan memanfaatkan tanah secara kolektif dalam sistem ejido. Situasi ini berubah pada tahun 1991 ketika pemerintah Salinas membuka akses bagi masuknya kapital asing serta mendorong privatisasi atas tanah. Kebijakan pemerintah Mexico ini sungguh menjauhkan masyarakat pribumi kecil dari sumber sosialekonomi, dan menyebabkan modal terkonsentrasi pada kelas elit yang baru. Hal ini semakin diperparah oleh keikutsertaan Mexico yang menuruti instruksi-instruksi NAFTA, IMF, dan Bank
Dunia dalam mengatasi krisis di negaranya. Dampak akut dari reformasi kebijakan itulah yang membidani lahirnya pemberontakan Zapatista di Chiapas pada tahun 1994 (Harvey 2009: 171) .

Selain melalui privatisasi dan komodifikasi "the commons" sebagaimana dijelaskan dimuka, akumulasi melalui penjarahan dilakukan pula lewat tahap yang jauh lebih canggih seperti finansialisasi, manajemen dan manipulasi krisis, serta redistribusi oleh negara (Harvey 2009:237). Praktek-praktek dalam bidang keuangan tersebut dimainkan oleh tiga aktor utama neoliberal yakni WTO, IMF, dan Bank Dunia yang mana praktek dan kebijakan mereka sangat spekulatif dan predatoris. The Bretton Woods (Bank Dunia dan IMF) berperan "memanfaatkan krisis hutang global untuk menertibkan.....dan mengebiri kemampuan pemerintah Dunia Ketiga dalam menghadapi negaranegara Utara, sejumlah korporasi, dan agen multilateral yang didominasi oleh Utara" (Danaher 2005:xiv). Pinjaman dari lembaga-lembaga tersebut dapat diberikan sejauh negara-negara penerima bantuan bersedia melaksanakan program penyesuaian struktural (Structural Adjusment Programs/SAPs). Dan, sesudah mengintegrasikan SAPs, pola ketergantungan satu negara miskin kepada negara maju tidak dapat dipungkiri lagi keberadaannya.

Jadi, secara ringkas dapat ditegaskan bahwa, terdapat empat aspek akumulasi melalui penjarahan menurut Harvey, yakni privatisasi dan komodifikasi, proses finansialisasi, manajemen dan manipulasi krisis, serta redistribusi oleh negara (Harvey 2005:160-165). Di atas semua hal ini, akumulasi melalui penjarahan dipengaruhi secara adekuat oleh 
Jurnal Pemikiran Sosiologi Volume 4 No. 2, 2017

Akumulasi Kapital, Penghancuran Gerakan Kiri, dan Kemiskinan di Timor

Didimus Dedi Dhosa

kekuatan negara, dalam apa yang Harvey sebut "negara neoliberal".

\section{Kolonialisme, Akar Akumulasi Kapital dan Kelanjutannya di Masa Pascakolonial}

Akumulasi kapital telah berlangsung dalam sejarah panjang kolonialisme di Timor. Kekayaan alam yang tersebar di seantero pulau Timor dahulu kala telah memantik hasrat bangsa-bangsa asing berlayar menuju pulau ini ${ }^{3}$. Sudah sejak abad ke-6 para musafir cum pedagang asal China berlayar ke pulau Timor sambil membawa porselin dan sutra untuk dipertukarkan dengan cendana (Wuryandari 2014:101). Pada awal abad ke-12, selain kayu harum cendana, Timor dikenal pula sebagai daerah penghasil madu, dan lilin (Neonbasu 2013:30), bahkan menurut catatan Zondervan seperti dijelaskan Neonbasu, 2013: 35, “masyarakat pedesaan Timor sudah menggunakan emas sebagai alat tukar dan uang resmi dalam perdagangan." Fakta ini mendorong Portugis sebagai bangsa pertama Eropa mendarat di Timor pada abad ke-15, yang disusul Belanda satu abad berikutnya yakni abad ke-16 (Wuryandari, 2014:101).

Awal-mula kedatangan para bangsa asing sematamata bertujuan mengembangkan usaha dagang.

\footnotetext{
${ }^{3}$ Asal-usul nama pulau Timor berasal dari sudut pandang yang bervariasi. Untuk kepentingan tulisan ini, penulis hanya menggunakan dua versi, pertama, tradisi lisan orang Tetun dan Bunak menyebut Ti'i mor sebagai alat pengolah kapas yang menjadi benang, karena alat ini dipakai oleh hampir seluruh orang-orang di Timor, maka nama alat ini dijadikan semacam penanda bagi pulau ini. Versi kedua, nama Timor berasal dari salah satu dokumen China abad ke-15 yang ditulis oleh Chau Ju Kua, menyebutkan kata Tiwu merujuk pada daerah yang kaya akan kayu cendana -Timor (Neonbasu 2016:117). Tapi, data 'abad ke-15' Neonbasu ini berbeda sangat tegas
}

Tapi, usaha dagang itu mulai bergeser menjadi kolonialisme atas Timor. Hal ini menyebabkan terjadinya disparitas sosial-ekonomi yang sukar dijembatani antara penguasa dan rakyat jelata, antara elit dan massa rakyat di Timor hingga saat ini. Para musafir berhasil mengakselerasi akumulasi kapital di Timor melalui dua cara. Pertama, perkawinan politis antara kolonial dengan penguasa lokal. Para musafir menikahi para putri raja atau keluarga dekat para raja. Dengan pernikahan ini penguasa asing dapat bersahabat dengan penguasa lokal. Persahabatan ini mempererat relasi kuasa diantara mereka, dan karena itu memudahkan para musafir untuk mendapatkan hasil-hasil bumi dari pulau Timor (Neonbasu, 2013:31; Parimartha, 2002:251).

Kedua, perjanjian "Paravicini" (contract paravicini). ${ }^{4}$ Perjanjian ini terjadi pada tahun 1756 antara Belanda dengan suku-suku di Timor. Kontrak tersebut menetapkan bahwa penguasa lokal wajib mengakui otoritas Belanda, semua raja bersekutu dengan unit kesatuan dagang Belanda (VOC), dan melarang hubungan penguasa Timor dengan bangsa-bangsa lain di pelabuhan dan di kediaman tanpa izin terlebih dahulu pada penguasa setempat (Ardhana, 2005:49).

dengan data yang ditayangkan Ormeling (1957:95), yang menyebutkan bahwa inspektor China Chau Ju-Kua itu merujuk Tiwu (Timor) sebagai daerah penghasil cendana pada tahun 1225 atau 'abad ke-13'

4 Paravicini diadopsi dari nama seseorang yang merancang perjanjian antara Belanda dengan para raja dan suku-suku di Timor. Ia bekerja sebagai pegawai pada zaman VOC Belanda. Perjanjian itu dibuat agar Belanda merasa aman dan tidak takut baik kepada raja maupun kepada masyarakat Timor. Dengan kata lain, kontrak paravicini adalah bentuk desakralisasi kekuasaan rajaraja di Timor. 
Jurnal Pemikiran Sosiologi Volume 4 No. 2, 2017

Akumulasi Kapital, Penghancuran Gerakan Kiri, dan Kemiskinan di Timor

Didimus Dedi Dhosa

Sebetulnya, contract Paravicini adalah bentuk sandiwara Belanda yang hendak menipu masyarakat, serta menanamkan pengaruh penjajah bagi kehidupan sosial masyarakat Timor. Melalui kontrak ini, masyarakat diarahkan agar tetap hidup meskipun berada dibawah tekanan Belanda. Warga yang fasih berbicara diangkat menjadi pembantu Belanda, bahkan sebagiannya diangkat menjadi raja walau mereka sebenarnya bukan turunan raja atau sama sekali tidak punya ikatan kerabat dengan para raja dalam arti tegas. Karena itu, contract paravicini dapat dilihat sebagai sebuah taktik kepengaturan yang memecah-belah masyarakat, yang mengurangi otoritas para pemimpin/raja di Timor (Neonbasu, 2013:39-41; Ataupah, 1992:187-189; Fox, 1977). ${ }^{5}$

Untuk memulus akumulasi kapital, selain melalui perkawinan politis dan kontrak Paravicini, Belanda juga melakukan pemisahan wilayah Timor ke dalam dua bagian: Timor bagian timur dan Timor bagian barat. Belanda menghubungi Portugis melakukan pembagian pulau Timor, yang dilaksanakan di Lisabon dan Nederland pada tahun 1854. Hasil pembagian itu diumumkan dan kemudian ditandatangani di Nusantara pada tahun 1859, serta disahkan pada tahun 1860. Sejak itulah, dua negara kolonial, Belanda dan Portugis, masing-masing menanamkan pengaruh dan kuasanya di dua tempat tersebut. Belanda menguasai Timor bagian barat,

\footnotetext{
5 Guna memperluas kekuasaan Belanda di Timor, maka diadakan "perjanjian plakat pendek" pada tahun 1913. Kurang-lebih tiga isi perjanjian ini antara lain: 1) penguasa lokal menyerahkan wilayahnya di bawah pengawasan kolonial Belanda; 2) pemerintah lokal dilarang melakukan hubungan dagang dengan penguasa dari bangsa-bangsa lain; 3) para elit lokal menyetujui undang-undang dan peraturan yang ditetapkan di dalam perjanjian dengan Belanda (Ardhana 2005:88,101).
}

sedangkan Portugis mengurusi Timor bagian timur (Neonbasu 2013:41-42).

Sejarah panjang penjajahan bangsa-bangsa asing terhadap Timor merupakan sebab paling besar kemiskinan sistemik baik yang dialami di masa lalu maupun yang dirasakan saat ini pada masyarakat Timor. Dalam perkataan lain, kemiskinan di Timor saat ini adalah warisan masa lalu kolonialisme dalam tiga aspek yakni: (1) pembabatan kayu cendana secara masif, (2) praktek penguasaan tanah, (3) serta kepemilikan ternak sapi yang terintegrasi dalam struktur kekuasaan yang timpang yang akan dijelaskan lebih lanjut pada sub bab berikutnya dalam artikel ini.

Struktur kekuasaan yang timpang di Timor dapat dipahami dalam konsepnya tentang kekuasaan yang sakral dan yang profan. Yang sakral terinstitusionalisasi dalam diri Maromak Oan yang menjalankan urusan kerohanian, sedangkan kekuasaan duniawi dipegang oleh raja (liurai). Raja atau 'Liurai' adalah pemegang otoritas tertinggi. Selama menjalankan sistem pemerintahan tradisional, raja dibantu oleh para fetor yang tinggal di daerah. Relasi antara raja dan bawahan ditengarai oleh fetor. ${ }^{6}$ Peran fetor yang relatif besar membuat fetor kerap kali dipandang sebagai raja-raja kecil yang hampir saja terlepas dari pantauan ketat para raja. Fetor dibantu oleh temukung. Temukung mengepalai wilayah di tingkat desa (kampung).

\footnotetext{
6 Jauh sebelum menggunakan istilah swapraja, fetor, dan temukung (Ormeling 1957:9), sudah ada sebutan lain dalam kebudayaan orang Timor diantaranya: Usif, Amaf, dan Tob. Posisi fetor di sini acapkali tumpang-tindih, dimana di daerah tertentu di Timor, ia bisa saja menyebut dan atau mengangkat dirinya sebagai Raja (Neonbasu 2016:32).
} 
Jurnal Pemikiran Sosiologi Volume 4 No. 2, 2017

Akumulasi Kapital, Penghancuran Gerakan Kiri, dan Kemiskinan di Timor

Didimus Dedi Dhosa

Temukung atau kepala desa memimpin sekitar 10-

50 keluarga di wilayahanya. Ia bertugas mengumpulkan pajak. Lebih dari itu, ia pun mengerahkan tenaga bagi raja dan bagi fetor. Akhirnya, guna memperkokoh kekuasaan sang raja, dibentuk pasukan prajurit yang acapkali diambil dari orang-orang yang memiliki ikatan darah dengan raja, bernama orang brani atau meo (Parimartha, 2002:74,78,79). Konsep kekuasaan tersebut diperluas ke dalam stratifikasi sosial masyarakat Timor.

Orang Timor mengenal empat golongan masyarakatnya yakni golongan atoni usif sebagai kaum bangsawan atau raja, atoni naik yang berasal dari kalangan orang-orang besar misalnya pegawai pemerintahan Belanda dan para pedagang, golongan tobe atau rakyat, dan terakhir, golongan ate atau para budak (Parera 1971:48-49; Parimartha 2002:78).

Struktur kekuasaan ini berpengaruh kuat dalam akses terhadap basis produksi dan upeti yang diterima sebagai pendapatan dalam urusan perdagangan. Pada era prakolonial, sistem upeti disebut "poni'. Raja berhak mendapat upeti dengan pembagian 1/5 dari hasil panen dan hasil hutan (khususnya cendana) dikumpulkan oleh petugas dan diserahkan pada raja. Namun, pada saat kolonial Belanda mulai menancapkan kuku kekuasaan di Timor, sistem perpajakan turut berubah. Masingmasing raja memiliki upeti yang berbeda, tergantung pada penghasilan penduduk. Raja Belu, misalnya, mendapatkan 5-6\% dari hasil penjualan kayu (Ardhana 2005:141). Penghasilan raja diambil dari pajak berupa hasil bumi yang dikumpulkan oleh para temukung dari penduduk. Dari hasil pertanian (seperti jagung dan padi), raja mendapat $1 / 4$ dari hasil panen (Parimartha 2002:84-85).

Sejak tahun 1611 Belanda menguasai Timor, salah satunya melalui perjanjian antara Belanda dengan para raja di Timor, yang isinya bahwa raja-raja tidak diperbolehkan menjual hasil bumi kepada pihak lain selain kepada VOC. Bahkan, Belanda membiarkan praktek pembabatan kayu cendana oleh penduduk secara bebas, dengan syarat, 1/3 hasil penebangan diserahkan bagi Belanda (Raharjo dkk 2013:5).

Monopoli perdagangan cendana oleh Belanda menyebabkan jumlah pengiriman cendana semakin berkurang dari periode ke periode. Data menunjukkan bahwa pada tahun 1910-1913, volume cendana yang diekspor rata-rata per tahun mencapai 8.500 pikul. Pada tahun 1914 cendana yang diperdagangkan tercatat 2.244 pikul dengan harga 70.409 gulden. Tahun 1915, jumlah cendana yang dijual sebanyak 1.146 pikul seharga 32.530 gulden. Tahun 1916 jumah cendana sebanyak 2.784 pikul seharga 76.479 gulden. Volume perdagangan cendana asal Timor kian menurun drastis pada tahun 1932 yang hanya mencapai 600 pikul, yang mana 1 pikul sama dengan 62,5 kg (Raharjo dkk. 2013:5).

Sesudah Indonesia merdeka, khususnya sebelum NTT terbentuk sebagai sebuah propinsi otonom, pola pengelolaan cendana tampak merujuk pada Peraturan Daerah Timor Nomor 4 Tahun 1953, dengan pola pembagian hasil jual cendana adalah, rakyat menerima premi sebesar 40 sen/kg; Pahtuaf menerima premi $20 \mathrm{sen} / \mathrm{kg}$; Temukung menerima premi 15 sen/kg; Fetor menerima premi 7,5 sen/kg; kepala swapraja menerima premi 5 sen/kg. Tapi, setelah NTT terbentuk secara resmi menjadi sebuah 
Jurnal Pemikiran Sosiologi Volume 4 No. 2, 2017

Akumulasi Kapital, Penghancuran Gerakan Kiri, dan Kemiskinan di Timor

Didimus Dedi Dhosa

Propinsi pada tahun 1958, maka pengelolaan cendana mengalami pergeseran yakni dilakukan oleh Pemerintah Daerah Tingkat I Nusa Tenggara Timur, dengan rujukan undang-undang pengelolaan cendana sebagai berikut: Perda Provinsi NTT Nomor 11/PD/1966; Perda Provinsi NTT Nomor 8/PD/1968 tentang perubahan Perda Provinsi NTT Nomor 11/ PD/1966; Perda Provinsi NTT Nomor 17 Tahun 1974 tentang perubahan atas pasal 6 dan pasal 9 Perda Provinsi NTT Nomor 11/PD/66; Perda Provinsi NTT Nomor 7 Tahun 1980 tentang perubahan perda Provinsi Nomor 11/PD/1966. Perda tersebut menegaskan bahwa "[s]eluruh cendana yang ada di wilayah NTT menjadi milik pemerintah" (Raharjo 2013:5-6).

Selanjutnya, Perda Nomor 7 Tahun 1980 tentang pengaturan pembagian hasil jual cendana yakni: 50\% untuk Pemerintah Daerah Tingkat I, dan 50\% untuk Pemerintah Daerah Tingkat II. Pada tahun 1986, terbit Perda Provinsi NTT Nomor 16 Tahun 1986 yang menyebutkan bahwa pembagian hasil penjualan cendana dibagi untuk Pemerintah Daerah Tingkat Kabupaten sebesar 50\% dan Pemda Provinsi sebesar 50\%, namun menariknya bahwa pemerintah Kabupaten diwajibkan untuk mengalokasikan $50 \%$ hasil penjualan kayu cendana yang mereka terima itu untuk kegiatan reboisasi (Raharjo 2013:6).

Lambat laun dominasi pengelolaan cendana oleh kolonial, raja, dan negara yang mengatur melalui seperangkat kebijakan dan undang-undang membuat penduduk teralienasi dari cendana miliknya. Penduduk lokal sama sekali tidak berhak atas cendana baik yang tumbuh di kebun petani maupun yang tumbuh di pekarangan rumah mereka. Ini ditandai oleh sanksi yang bakal diterima penduduk manakala cendana rusak dan berakhir mati.

Selain dominasi pengelolaan cendana, ada pula dominasi kepemilikan tanah dan ternak oleh elit. Parimartha (2002:85) menyebutkan bahwa, raja di Timor tidak memiliki tanah dalam arti seluasluasnya. Kekayaan raja adalah para budak, upeti, dan ternak. Pihak yang memiliki tanah adalah temukung dan fetor. Tanah-tanah adalah milik suku, dan kepala suku dapat memberikan kepada setiap anggota untuk menggarapnya, walaupun penduduk setempat sering mengaku bahwa tanah itu milik raja. Meski raja tidak memiliki tanah dalam arti yang seluas-luasnya, namun struktur kekuasaan sangat menguntungkan raja dalam bidang ekonomi-politik, karena ada "poni" yakni pajak yang diterima oleh raja dan para pemimpin lainnya. Raja juga memilik ternak serta kontrol atas perdagangan yang meningkatkan kekayaan dalam bidang ekonomipolitiknya. Berbeda dengan Parimartha, Ormeling sebagaimana dijelaskan Klinken (2015:104-105) menyebutkan, konsentrasi tanah terdapat pula pada para raja, khususnya raja di Kabupaten Belu, Mollo (TTS), dan Amarasi (di Kabupaten Kupang). Bahkan, konsentrasi penguasaan lahan pada kaum elit tradisional yang awal mula dikuasai oleh petinggi kultural telah mengalami metamorfosa yang kemudian didominasi oleh pihak keluarga tertentu di Timor (Djese dkk. 2015).

Sejak tahun 1920 Belanda mengintrodusir pemeliharaan sapi bali di Timor. Para raja memiliki privilese mendapatkan ternak karena mereka memilik cukup jaminan untuk mendapatkan kredit. Baru pada tahun 1930-an, fetor dan temukung ditawarkan untuk menerima ternak sapi. Konsentrasi kepemilikan ternak berada pada elit 
Jurnal Pemikiran Sosiologi Volume 4 No. 2, 2017

Akumulasi Kapital, Penghancuran Gerakan Kiri, dan Kemiskinan di Timor

Didimus Dedi Dhosa

(Klinken 2015:102-103; Ormeling 1957:187). Menurut laporan yang dikutip dari Ataupah (1992:496), pada tahun 1924 jumlah sapi yang terdaftar sebanyak 3.021, sedangkan pada tahun 1930 jumlah sapi meningkat menjadi 7.323. Jumlah ini tidak merepresentasikan kepemilikan ternak secara tepat. Penduduk tidak melaporkan jumlah sapi secara jujur untuk didata disebabkan beberapa faktor. Pertama, penduduk ingin menghindar dari tuntutan membayar pajak ternak. Semakin banyak jumlah ternak, maka makin besar pula jumlah pajak yang mesti dibayar, dan ini merugikan mereka. Kedua, sapi-sapi diberikan kepada sanak kerabat untuk dipelihara di padang-padang yang berbeda, dan dimasukan pula ke dalam kandang-kandang yang berbeda. Jumlah sapi yang dimasukan ke dalam kandang bisa mencapai 125 ekor. Di Hue Knufu, salah satu lokasi penelitiannya, Ataupah melaporkan, "terdapat 15 pemilik ternak yang memiliki 200 sampai lebih 1000 ekor sapi. Tetapi tidak seorang pun diantara pemilik sapi itu tercatat secara resmi memiliki lebih dari 25 ekor sapi dalam buku register desa mereka masing-masing". Masingmasing dari mereka berdalih telah membagikan sapi kepada sanak keluarga untuk terbebas dari jerat pajak" (Ataupah 1992: 121,123-124). Pada tahun 1950-an, diperkirakan 40\% ternak sapi dipasok oleh raja, fetor, dan temukung, $40 \%$ berikutnya dipasok oleh para pedagang Tionghoa, dan 20\% dari orang Timor pada umumnya (Klinken 2015:103, bahkan menurut laporan Barlow pada tahun 1991, sebagaimana dikutip Klinken (2015:327) menyatakan bahwa ternak semakin terkonsentrasi pada elit dimana " $4,5 \%$ petani dengan jumlah sapi di atas 25 memiliki 48,4\% dari semua sapi dan kerbau, sedangkan 55\% rumah tangga petani hanya memiliki satu atau dua ekor ternak".

Sesudah padang rumput mengalami kerusakan hebat akibat banyaknya sapi berkeliaran di dalamnya sebagai milik bersama, sapi-sapi itu dibiarkan mencari pakan dan air di areal pertanian yang pada akhirnya menyebabkan persaingan antara usaha ladang dan ternak yang sama-sama membutuhkan lahan. Kerusakan itu diperparah dengan tiadanya upaya sistematis merawat padang rumput dengan cara menanam kembali tanaman pakan ternak untuk dipakai dalam jangka waktu yang panjang dan berkelanjutan (Ataupah 1992:124-125), serta di atas semua itu, tidak adanya gerakan massa rakyat yang kuat membuat dominasi pengelolaan cendana, konsentrasi kepemilikan lahan dan ternak tetap berada pada lingkaran elit, daripada ditransformasi pada massa rakyat yang akan dijelaskan pada bagian berikutnya.

\section{Privatisasi dan Komodifikasi Sumberdaya Alam di Nusa Tenggara Timur}

Praktek privatisasi di Indonesia telah berlangsung secara masif dan sistematis sejak era kekuasaan Soeharto. Sejak diberlakukan undang-undang penanaman modal asing dan penanaman modal dalam negeri (1967/1968), privatisasi terhadap BUMN serta terhadap sumber daya produksi di dalam negeri kian marak. Negara memfasilitasi masuknya modal asing ke dalam negeri yang membuat ribuan hektar tanah milik ulayat beralih fungsi menjadi tanah yang dikelola hak guna usaha (HGU) oleh korporasi-korporasi, serta raibnya lingkungan akibat eksploitasi tambang secara nasional. 
Jurnal Pemikiran Sosiologi Volume 4 No. 2, 2017

Akumulasi Kapital, Penghancuran Gerakan Kiri, dan Kemiskinan di Timor

Didimus Dedi Dhosa

Di Timor, tanah-tanah ulayat yang semestinya dipakai untuk pemenuhan kebutuhan para petani justeru beralih fungsi pengelolaan baik untuk kepentingan pengembangan tanaman industri maupun untuk eksplorasi tambang oleh korporasi. Hak-hak adat orang Atoni Meto terhadap tanah dihapus oleh negara. Luas lahan sebesar kuranglebih 20.000 hektar telah beralih fungsi dari tanah adat masyarakat Biboki-TTU kepada PT Fendi Hutani Lestari (FHL). Selanjutnya, perusahaan ini pula yang menguasai 25.000 hektar tanah di PollenTTS. FHL merupakan perusahaan pemegang hak penguasaan hutan tanaman industri (HPHTI) selama rentang waktu 45 tahun, terhitung sejak 1995. Pihak yang memberikan keputusan akan HPHTI adalah Departemen Kehutanan yang ditandatangai pada tahun 1995 (Ruwiastuti 2000:51-59).

Pada awal mula FHL menjanjikan masyarakat setempat untuk boleh memasuki kawasan HGU, menanamkan tanaman pangan semusim di areal tersebut, serta berjanji akan merekrut masyarakat setempat menjadi pekerja di tempat ini. Tapi, apa yang dijanjikan itu tidak lebih dari sekedar kamuflase picik. Maka, lahirlah perlawananperlawanan massa rakyat yang tampak sporadis untuk merebut kembali sumber daya penduduk yang diduduki perusahaan ini.

Berhadapan dengan konflik tersebut, disposisi aparatus negara (Pemerintah Propinsi Nusa Tenggara Timur) tampak 'abu-abu'. Pemerintah Propinsi NTT merekomendasikan dua hal diantaranya 1) bagi FHL, gubernur berpesan agar mampu menghormati hak-hak adat masyarakat Biboki, memberikan kesempatan bagi mereka mengambil menfaat dari areal yang telah dikuasai oleh perusahaan; 2) bagi masyarakat Biboki, kepala Kehutanan propinsi meminta penduduk untuk senantiasa bersyukur, karena hadirnya FHL dapat membuka lapangan pekerjaan baru, dan menyerap mereka menjadi pekerja pada perusahaan itu (Ruwiastuti 2000:53).

Menurut Ruwiastuti (2000:54), sikap pemerintah Propinsi NTT dapat dijelaskan dalam tiga hal penting berikut ini, pertama, seolah-olah hak masyarakat Biboki hanya terbatas pada pengambilan menfaat dari tanah sehingga membiarkan korporasi tetap menguasai lahan; kedua, pemerintah mengakui bahwa FHL berhak menguasai dan menggunakan lahan-lahan yang disengketakan; dan ketiga, pemerintah beranggapan bahwa menjadi pekerja pada perusahaan FHL lebih penting daripada hilangnya akses penduduk atas tanah ulayat.

Selain pengambil-alihan status kepemilikan lahan dari tanah komunal dan diberikan kepada korporasi yang difasilitasi oleh negara Orde baru, privatisasi dan komodifikasi dilakukan pula melalui eksploitasi tambang yang mendapat legitimasi negara pasca reformasi di Timor.

Tambang telah menyebabkan dominasi korporasi bekerjasama dengan negara untuk mendominasi masyarakat lingkar tambang. Tambang menghadirkan kemiskinan pada masyarakat di lingkar tambang. Pertambangan menghasilkan degradasi sosial-budaya dan degradasi lingkungan. Pada akhirnya, tambang memarjinalisasi masyarakat lokal yang menggantungkan hidup pada alam lingkungan (Regus 2011). 
Jurnal Pemikiran Sosiologi Volume 4 No. 2, 2017

Akumulasi Kapital, Penghancuran Gerakan Kiri, dan Kemiskinan di Timor

Didimus Dedi Dhosa

\section{E. Dampak Penghancuran Gerakan Kiri Indonesia di Nusa Tenggara Timur}

Peristiwa penculikan dan pembunuhan terhadap enam jenderal Angkatan Darat dan kapten Pierre Tandean pada 01 Oktober 1965, [yang sering disebut G30S PKI], adalah cikal bakal lahirnya penghancuran gerakan kiri ke segenap penjuru Indonesia yang menewaskan kurang-lebih 500.000 orang pada tahun 1965-1966 (Cribb 2001:219). Peristiwa tersebut dipahami dalam dua konteks historis, yang satu bersifat internasional, dan yang lainnya bersifat nasional. Pertama, dalam aras internasional, terjadi perang dinging antara blok kapitalis di bawah kendali Amerika Serikat bersama sekutu-sekutunya, dan blok sosialis di bawah pimpinan Uni Soviet. Perang dingin ini menyebabkan negara-negara dunia ketiga menjadi rebutan dan target untuk menanamkan pengaruh ideologis antara kapitalisme versus komunisme (White 2015:3-4). Kedua, dalam skop nasional, merujuk pada Cornel Paper, pembunuhan itu dilatari oleh konflik internal angkatan darat antara golongan tua versus golongan muda. Konflik dimaksud cenderung bermuara pada perebutan sumber ekonomi-politik pasca nasionalisasi perusahaan-perusahaan asing yang dikelola oleh militer dan pengusaha China (Robison 2012).

Sesudah peristiwa genting 1 Oktober 1965, terjadi pembantaian terencana dan sistematis bagi anggota Partai Komunis Indonesia (PKI), siapa saja yang diduga bagian dari partai ini, serta orang-orang yang berafiliasi dengan PKI, diantaranya GERWANI (Gerakan Wanita Indonesia), LEKRA (Lembaga Kebudayaan Rakyat), BTI (Barisan Tani Indonesia), dan SOBSI (Serikat Organisasi Buruh Seluruh
Indonesia) (White 2015:3). Para korban PKI terbagi atas tiga tipe yakni pertama, kategori A merupakan orang-orang yang dibawa ke depan pengadilan dan dieksekusi mati; kedua, kategori B adalah orang penting, meski tidak terbukti melakukan suatu pelanggaran, mereka tetap ditahan tanpa melewati proses pengadilan, disiksa hingga dibuang ke pulau Buru, dan ketiga, kategori C yakni orang yang sesudah ditangkap, dilepaskan dan dibiarkan kembali ke masyarakat dengan sejumlah stereotip yang melekat bertuliskan "ET" (eks tapol) pada KTP, dengan pelbagai konsekuensi sosial (Suseno 2015:3$5)$.

Meski secara kelembagaan PKI tidak cukup kuat lagi, penganiayaan terhadap PKI dirasakan begitu kejam dan tidak berperi-kemanusiaan pasca Oktober 1965. Max Lane (2013) sebut peristiwa 1965 sebagai "gerakan kontra revolusi". Tampaknya, pembunuhan secara bengis ini didorong oleh ketakutan rezim Soeharto, TNI AD, serta asing (AS) terhadap PKI yang memiliki program-program populis khususnya land reform, yang justifikasinya melalui Undang-Undang Pokok Agraria (UUPA) tahun 1960.

Pada prinsipnya, UUPA lahir sebagai tanggapan atas sistem agraria yang timpang warisan kolonial. Negara melalui UU ini hendak merombak tatanan hukum yang cenderung berpihak pada elit tuan tanah, kaum agamawan, dan korporasi. Sesudah merombak sistem kepemilikan tanah tersebut, masyarakat diberikan kemudahan untuk memiliki lahan seturut ketetapan negara. Batas minimum luas tanah yang diatur UUPA ini sebesar dua hektar bagi tiap keluarga inti, sedangkan luas maksimum tanah tergantung pada luas wilayah dan kepadatan penduduk tiap-tiap daerah. Dengan demikian, para 
Jurnal Pemikiran Sosiologi Volume 4 No. 2, 2017

Akumulasi Kapital, Penghancuran Gerakan Kiri, dan Kemiskinan di Timor

Didimus Dedi Dhosa

petani diberikan kepastian hukum kepemilikan tanah sebagai basis produksi (Soemardjan, 1984:106-107).

Sebelum diterapkannya UUPA tahun 1960, terjadi tiga peristiwa (UU) penting yang mendahuluinya yakni: pertama, pada tahun 1945 dilakukan penghapusan hak istimewa desa perdikan di Banyumas (Jawa tengah), dari pembayaran pajak tanah dan dari pola kepemimpinan di tingkat desa yang diwariskan turun-temurun. Kedua, melalui UU darurat No. 13 tahun 1948, negara mengambil-alih tanah-tanah yang dikuasai oleh 40 perusahaan gula Belanda di Kasultanan Yogyakarta dan Surakarta. Ketiga, melalui UU No. 1 tahun 1958 negara menghapus semua tanah partikelir beserta hak-hak privilese yang dipegang oleh tuan tanah, sambil mengambil-alih kepemilikan itu untuk diberikan kepada penduduk dalam dua cara: para tuan tanah menjual langsung lahan-lahan pada para petani Indonesia dengan harga tanah ditentukan oleh negara, atau menyerahkan tanah kepada negara untuk kemudian dibagikan kepada penduduk (Soemardjan 1984:104-105).

Dua tahun berikutnya, tepat pada tahun 1960 diterbitkanlah UUPA. Namun, UU ini tidak berlangsung lama karena bandul kekuasaan berpindah ke tangan Soeharto. Target yang hendak dicapai Soekarno dan PKI untuk membuka akses yang lebih merata dan adil bagi masyarakat kecil pada akhirnya dipelintir. Sejak Soeharto dilantik menjadi Presiden RI, pelbagai hal yang berkaitan dengan Soekarno, serta program-program populis PKI [land reform] dihancurkan sama sekali.

Soeharto menetapkan UU No. 7 tahun 1970 untuk menghapus pengadilan land reform. Pada tahun
1980, muncullah Keputusan Presiden (Keppres) No. 55 tahun 1980 tentang organisasi dan tata cara land reform. Lewat keputusan ini yang mengurusi land reform bukan oleh panitia yang terdiri atas organisasi petani hingga tingkat desa sebagaimana terjadi pada era sebelumnya, melainkan dibuat oleh para petinggi berbagai departemen serta wakil dari Himpunan Kerukunan Tani Indonesia (Wiradi 1984:311).

Jadi, di tingkat nasional, penghancuran terhadap gerakan kiri terjadi melalui pembunuhan massal serta pembuatan regulasi-regulasi untuk menggantikan UUPA sebagai produk orde lama demi menghindari land reform.

Di tingkat lokal (Timor), land reform merupakan program yang mengganggu eksistensi raja, fetor dan temukung (Klinken 2015:271). Pasalnya, elit tradisonal ini memiliki sejumlah privilese dalam bidang upeti dari tiap transaksi cendana, lilin, hasil pertanian, serta menguasai ternak dan areal tanah yang sangat luas. Privilese ini memicu perlawanan dari sejumlah gerakan PKI di Timor.

Hampir sama dengan pembunuhan massal di Maumere-Flores pada tahun 1966, yang menewaskan 800-2000 orang, serta diamnya sikap gereja Katolik atasnya (Prior 2011:117-143), pembunuhan terhadap anggota PKI serta pelbagai organisasi yang berafiliasi dengan PKI tidak terlepas dari keterlibatan gereja, serta hasil asosiasi antara kelas menengah dengan militer. Para pemimpin gereja turut menangkap, menahan, dan mengeksekusi korban PKI. Bahkan, penahanan dan penyiksaan itu pernah dilakukan di dalam gedung gereja di Timor Barat (Kolimon 2015:92). 
Jurnal Pemikiran Sosiologi Volume 4 No. 2, 2017

Akumulasi Kapital, Penghancuran Gerakan Kiri, dan Kemiskinan di Timor

Didimus Dedi Dhosa

Gereja Protestan melihat PKI sebagai lawan. Gereja mengkriminalisasi PKI (Klinken 2015:273). Para pemuda GMIT (Gereja Masehi Injili di Timor) tahu persis dimana tempat tinggal para pemimpin PKI, melempari rumah mereka, serta menangkap mereka untuk kemudian diserahkan pada pihak militer. Ada tuntutan besar-besaran di Kupang untuk membubarkan PKI dan membasminya hingga akarakarnya. Anggota barisan tani Indonesia (BTI) yang datang dari arah pedalaman untuk menghadiri pertemuan-pertemuan di Kupang pada akhirnya diolok-olok, ditangkap dan 'dihabisi' oleh para preman. Untuk memperkuat gerakan pembasmian itu, dibentuk pula front pemuda anti komunis di Kupang. Front ini diresmikan dibawah perlindungan militer pada bulan Mei 1966. Sejumlah kaum muda Protestan, Katolik, dan Islam serta organisasiorganisasi pelajar dan mahasiswa lainnya turut melakukan aksi-aksi pengusiran dan penangkapan terhadap siapa saja yang diduga PKI. Sesudah ditangkap oleh kelompok pemuda ini, anggota PKI diserahkan pada militer, dan tak lama berselang dibunuh pula oleh militer (Klinken 2015:288-291).

Sebagian besar para korban yang dibunuh tidak melewati proses pengadilan secara terbuka, apalagi pengadilan militer tidak ada di Kupang pada tahun 1965. Daftar nama-nama orang yang hendak dieksekusi diambil dari beberapa sumber, diantaranya, disusun oleh intelijen militer (Kasi Intel) yang berkedudukan di Kupang; nama pemimpin senior PKI dan BTI diambil dari yang disiapkan oleh komite partai dan diberikan pada pihak pemerintah; dan nama-nama pemimpin yunior PKI diambil dari daftar nama calon penerima bantuan dari pemerintah selama masa paceklik melanda Timor pada tahun 1964-1965 dalam program Mekatani (Klinken 2015:296-297).

Para korban PKI tidak diperbolehkan menghadiri perayaan gerejani. Anak-anak yang dilahirkan dari keluarga PKI tidak menerima sakramen baptis dalam rentang waktu yang lama. Mereka sulit mendapat pekerjaan yang layak dalam birokrasi. Mereka dicap sebagai komunis, diasingkan secara sosial, dan mendapat perlakuan diskriminatif dalam urusan-urusan sosial-keagamaan. Sementara itu, para pelaku pembantaian massal diperlakukan sebagai pahlawan di dalam GMIT. Mereka mendapat perlakuan istimewa, tanpa harus mengakui kesalahan di hadapan gereja (Kolimon 2015:93; Kolimon dan Wetangterah 2012).

Hal-hal yang dijelaskan di muka, pada akhirnya menyisahkan paling tidak tiga hal. Pertama, peristiwa 1965 menurut Douglas Kammen dan Kate McGregor sebagaimana dikutip dari McNaughton (2015:301), tidak sekedar pembantaian atas gerakan kiri, tetapi lebih dari itu, sebagai suatu bentuk re-organisasi kekuatan-kekuatan sosial, dan dengan demikian mengintegrasikan Indonesia ke dalam suatu sistem ekonomi dunia kapitalis. Bahkan, lanjut McNaughton (2015:302) dengan mengutip Naomi Klein menyebutkan, genosida sebagai model kontra-revolusi bukan saja berhasil di Indonesia, melainkan juga ia telah menjadi model kontra-revolusi yang 'diekspor' secara global oleh US ke negara-negara lain.

Kedua, pembantaian massal tahun 1965 telah menyebabkan agenda-agenda nasional kocar-kacir. Land reform terlantar dan tampak tabu untuk diperbincangkan bertahun-tahun lamanya. Pengadilan dan komite reforma agraria dileburkan 
Jurnal Pemikiran Sosiologi Volume 4 No. 2, 2017

Akumulasi Kapital, Penghancuran Gerakan Kiri, dan Kemiskinan di Timor

Didimus Dedi Dhosa

secara formal pada tahun 1970. Program populis Barisan Tani Indonesia (BTI) 'bimbingan masyarakat' yang bekerjasama dengan kampuskampus untuk membantu meningkatkan produksi pertanian malah digantikan dengan program 'gotong-royong' yang bekerja sama dengan koorporasi multinasional demi suksesnya 'revolusi hijau' (White 2015:12), kini ditengarai sebab pemiskinan sistemik.

Ketiga, di Timor, land reform yang pernah dilaksanakan di Kabupaten Kupang dan Timor Tengah Selatan, bertepatan dengan peringatan Hari Petani Nasional, dimana beberapa ratus hektar tanah negara dihibahkan kepada massa rakyat terhenti total pada masa-masa selanjutnya. Ekses besar kemudian adalah matinya gerakan kiri yang memperjuangkan hak-hak massa rakyat atas basis produksi, dan terbungkamnya gereja berpihak pada kepentingan para petani. Konsekuensi lanjut lainnya adalah terbatasnya akses massa rakyat kepada sumber daya produksi pada satu sisi, dan konsentrasi kepemilikan basis produksi tetap berada di tangan segelintir elit di Timor pada sisi yang lain hingga saat ini.

\section{F. Kesimpulan}

Kemiskinan di Timor pertama-tama bukan disebabkan oleh faktor alam yang tandus, infrastruktur yang kurang memadai, sumber daya manusia yang minim, maraknya praktek korupsi oleh elit birokrasi, serta pengabaian prinsip-prinsip good governance dalam otonomi daerah, seperti dibayangkan para peneliti LIPI (Wuryandari 2014). Argumentasi itu tampak tidak menyentuh persoalan paling mendasar, sengaja menyembunyikan atau mengabaikan permasalahan ekonomi-politik, yang Li (2012) sebut "teknikalisasi persoalan".

Sebaliknya, kemiskinan di Timor disebabkan terutama oleh akumulasi kapital dan penghancuran gerakan kiri sampai ke akar-akarnya. Akumulasi kapital berlangsung bukan hanya dalam format primitif (Karl Marx), melainkan juga terkristal dalam akumulasi melalui penjarahan (David Harvey), yang meliputi sejarah panjang kolonialisme serta privatisasi dan komodifikasi. Melalui dua cara tersebut, kayu cendana sebagai kekayaan utama orang Timor dimusnahkan oleh kolonial dan dikuasai pengelolaannya oleh negara pasca kolonial. Kepemilikan ternak dikuasai oleh raja, fetor, temukung, dan pengusaha China. Tanah tetap terkonsentrasi pada elit-elit lokal. Dan, melalui penghancuran gerakan kiri, tidak ada lagi gerakan sosial alternatif yang adekuat memperjuangkan pembagian tanah yang lebih adil bagi massa rakyat, dan malah kian miris dengan terintegrasinya Indonesia umumnya dan Timor khususnya ke dalam sistem ekonomi dunia yang kapitalistik.

Sesudah menghancurkan gerakan kiri, kini negara memfasilitasi pengalihan tanah-tanah milik warga kepada korporasi. Proses pengalihan itu berlangsung karena kebijakan negara yang pro pada ekspansi kapitalisme global. Jika saat genosidal '65 negara melakukan kekerasan dan dominasi, maka sesudah '65 negara malah menggunakan modus operandi yang tampak halus - tanpa kekerasan, melalui kebijakan-kebijakan. Fakta ini pada akhirnya semakin menegaskan apa yang pernah diulas David Harvey - "negara neoliberal”. Negara neoliberal hanya mengejar indeks pertumbuhan ekonomi dan pendapatan perkapita, serta mengkotbahkan trickle down effect (efek tetesan ke 
bawah), lalu lupa pada tercerabutnya massa rakyat

Timor dari basis produksi milik mereka sendiri.

\section{Daftar Pustaka}

Ataupah, Hendrik. 1992. Ekologi, Persebaran Penduduk, dan Pengelompokan Orang Meto di Timor Barat. Disertasi. Jakarta: UI. Tidak Diterbitkan.

Ardhana, I Ketut. 2005. Penataan Nusa Tenggara Pada Masa Kolonial 1915-1950. Jakarta: Rajawali Pers.

BPS. 2017. Statistik Propinsi NTT 2016. Jakarta: Biro Pusat Statistik.

Cribb, Robert. 2001. "Genocide in Indonesia, 19651966", Journal of Genocide Research, 3 (2): 219-239.

Danaher, Kevin. 2005. 10 Alasan Bubarkan IMF \& Bank Dunia (Penerjemah: AB. Widyanta). Yogyakarta: Penerbit Cinderalas Pustaka Rakyat Cerdas.

Djese, Selsus Terselly dkk. 2015. Pendekatan Budaya Dalam Pelaksanaan Perbaikan Daya Dukung Lahan Padang Penggembalaan Ternak Sapi di Pulau Timor. Kupang: Badan Penelitian dan Pengembangan Daerah Propinsi NTT.

Fox, James. 1977. Harvest of the Palm, Ecological Change in Eastern Indonesia. Cambridge, Massachusetts, London: Harvard University Press.

Frank, Andre Gunder. 1966. “On National Development: The Development of Underdevelopment", dalam Sing C. Chew and Pat Lauderdale (ed), Theory and Methodology of World Development: The Writings of Andre Gunder Frank. United States: Palgrave Macmillan.

Hadiz, Vedi R. 2005. Dinamika Kekuasaan: EkonomiPolitik Indonesia Pasca-Soeharto. Jakarta: LP3ES.

2015. "Capitalism, Primitive Accumulation, and the 1960s Massacres: Revisting the New Order and its Violent". Inter-Asia Cultural Studies, 16(2): 306-315.

Harvey, David. 2003. New Imperialism. New York: Oxford University Press. ----. 2005. A Brief History of Neoliberalism. United States: Oxford University Press. ---. 2009. Neoliberalisme dan Restorasi Kelas Kapitalis (Penerjemah: Eko Prasetyo Darmawan). Yogyakarta: Resist Book.
Heertz Norena. 2004. "Hidup di Dunia Material: Munculnya Gelombang Neoliberalisme", dalam I. Wibowo dan Francis Wahono (ed), Neoliberalisme. Yogyakarta: Cinderalas Pustaka Rakyat Cerdas.

Hoselitz, B. 1960. Sociological Aspects in Economic Growth. New York: Free Press.

Klinken, Gerry van. 2015. The Making of Middle Indonesia: Kelas Menengah di Kota Kupang, 1930an - 1980-an. Jakarta: Yayasan Pustaka Obor Indonesia - KITLV-Jakarta.

Kolimon, Mery. 2015. "Para Pelaku Mencari Penyembuhan: Berteologi dengan Narasi Para Pelaku Tragedi '65 di Timor Barat", dalam Otto Gusti Madung dan John Mansford Prior (ed.), Berani Berhenti Berbohong: 50 Tahun Pasca Peristiwa 1965-1966. Maumere: Penerbit Ledalero, Litbang STFK Ledalero.

Kolimon, Mery dan Liliya Wetangterah (ed.). 2012. Memori-Memori Terlarang: Perempuan Korban \& Penyintas Trageri '65 di Nusa Tenggara Timur. Kupang: Yayasan Bonet Pinggupir.

Lane, Max. 2013. Unfinished Nation. Jakarta: Penerbit Djaman Baroe.

Li, Tania Murray. 2012. The Will to Improve: Perencanaan, Kekuasaan, dan Pembangunan di Indonesia. Jakarta: Marjin Kiri.

Marx, Karl. 2004. Kapital I: Sebuah Kritik Ekonomi Politik. (Penerjemah Oey Hay Djoen). Jakarta: Hasta Mitra.

McCelland, David. 1967. The Achieving Society. New York: Free Press.

McNaughton, Colm. 2015. "Reading the Mass Violence in Indonesia 1965-1966 as a Form of Primitive Accumulation". Inter-Asia Cultural Studies, 16 (2): 292-305.

Mulyanto, Dede. 2012. Genealogi Kapitalisme: Antropologi dan Ekonomi Politik Pranata Eksploitasi Kapitalistik. Yogyakarta: Resist Book.

Neonbasu, Gregor (Penyunting). 2013. Kebudayaan: Sebuah Agenda Dalam Bingkai Pulau Timor dan Sekitarnya. Jakarta: Gramedia.

Neonbasu, Gregor. 2016. Citra Manusia Berbudaya: Sebuah Monografi tentang Timor dalam Perspektif Melanesia. Jakarta: Antara Publishing.

Ormeling, F.J. 1957. The Timor Problem: a Geographical Interpretation of an Underdeveloped Island. The Hague-Holland: J. B Wolters, Groningen and Martinus Nijhoff. 
Parsons, Talcott. 1964. "Evolutionary Universals in Society". American Sociological Review. (June): 339-357.

Parimartha, I Gde. 2002. Perdagangan dan Politik di Nusa Tenggara 1815-1915. Jakarta: Perwakilan KITLV dan Penerbit Djambatan.

Parera, A.D.M. 1971. Sejarah Politik Pemerintahan Asli: Sejarah Raja-Raja di Timor. Kupang: Dokumen tidak diterbitkan.

Pye, Lucien. 1962. Personality, Politics, and Nation Building. New Haven, CT: Yale University Press.

Prior, John Mansford. 2011. "The Silent Scream of a Silenced History: Part One: The Maumere Massacre of 1966". Excange 40 (2011): 117143.

Raharjo, S.A.S. dkk. 2013. "Sejarah Dominasi Negara Dalam Pengelolaan Cendana di Nusa Tenggara Timur". Jurnal Manusia dan Lingkungan, Vol. 20, No. 1, Maret.

Regus, Maximus. 2011. "Tambang dan Perlawanan Rakyat: Studi Kasus Tambang di Manggarai, NTT". Masyarakat: Jurnal Sosiologi, Vol. 16, No. 1, Januari.

Robison, Richard. 2012. Soeharto \& Bangkitnya Kapitalisme Indonesia. Jakarta: Komunitas Bambu.

Rostow, W. 1960. The Stages of Economic Growth: A Non-Communist Manifesto. London: Cambridge University Press.

Ruwiastuti, Maria Rita. 2000. "Sesat Pikir", dalam Noer Fauzi (Penyunting), Politik Hukum Agraria. Yogyakarta: Insist Press, KPA, dan Pustaka Pelajar.

Samuel, Hanneman. 2010. Genealogi Kekuasaan Ilmu Sosial Indonesia: dari Kolonialisme Belanda hingga Modernisme Amerika. Jakarta: Penerbit Buku Kepik Ungu bekerjasama dengan LabSocio UI.

Soemardjan, Selo. 1984. "Land Reform di Indonesia", dalam Sediono M.P. Tjondronegoro dan Gunawan Wiradi (Penyunting), Dua Abad Penguasaan Tanah: Pola Penguasaan Tanah Pertanian di Jawa dari Masa ke Masa. Jakarta: Yayasan Obor-Penerbit Gramedia.

Suseno, Franz-Magnis. 2015. "Sesudah 50 Tahun Kita Harus Berani Menghadap Apa yang Terjadi", dalam Otto Gusti Madung dan John Mansford Prior (ed.), Berani Berhenti Berbohong: 50 Tahun Pasca Peristiwa 19651966. Maumere: Penerbit Ledalero, Litbang STFK Ledalero.

Tolo, Emilianus Yakob Sese. 2016. "Akumulasi Melalui Perampasan dan Kemiskinan di
Flores". MASYARAKAT: Jurnal Sosiologi 21 (2): 173-204.

White, Ben. 2015. "Remembering the Indonesian Peasants' Front and Plantation Workers' Union (1945-1966)", The Journal of Peasant Studies.

Wiradi, Gunawan. 1984. "Pola Penguasaan Tanah dan Reforma Agraria”, dalam Sediono M.P. Tjondronegoro dan Gunawan Wiradi (Penyunting), Dua Abad Penguasaan Tanah: Pola Penguasaan Tanah Pertanian di Jawa dari Masa ke Masa. Jakarta: Yayasan OborPenerbit Gramedia.

Wuryandari, Ganewaty (ed). 2014. Pengembangan Wilayah Nusa Tenggara Timur dari Perspektif Sosial: Permasalahan dan Kebijakan. Jakarta: LIPI Press.

\section{Sumber berita Koran/Majalah:}

Pos Kupang, Edisi 6 April 2017

Victory News, 29 Maret 2017. 